serious part of general education it will have to be amended.

Another factor, admittedly of less importance but still real, is the strict and indiscriminate application of the laws of priority, whereby old and universally known names are displaced by others discovered by antiquarian grubbing in forgotten publications. The motto here should be "let sleeping dogs lie", or "quieta non movere".

One result of all this is that an ordinary geologist who learnt his elementary work, say, forty or fifty years ago, when reading a modern stratigraphical paper often has a very vague idea of what it is all about, unless he happens to be a specialist in that particular subject. Sometimes the specific name may give him a clue to the identity of a fossil assigned to some genus of which he has never heard. Otherwise he may vainly hunt through much literature for an explanation.

This leads on naturally to another important side of the subject, namely, the effect of all this on the general view of geology taken by less specialized and especially by amateur readers; what may well be called the popular view. This can be simply summed up in a single phrase. Popular geology is being killed by pedantry, and even in schools and universities the subject is rendered so unattractive that few students select it. The falling off in the number of students of geology in many universities is notorious, but the special point to be made here is that this falling off is not the fault of the teachers, but of the state to which the science itself has been reduced by people who are not teachers, and moreover are not sufficiently men of the world to realize the disastrous effect on the science and its practical applications in the future of their well-meaning but wholly misdirected efforts.

Another instance may be mentioned as affecting what used to be a favourite field for amateurs, namely, the incessant introduction of new and uncouth names for minute sub-divisions of prehistoric cultures. This is usually considered to be part of geology, but it is really prehistoric archæology, and modern developments have made it quite unsuitable for inclusion in elementary teaching courses, owing to the multiplicity of detail. Students who take geology for any purpose beyond the mere attainment of a degree cannot afford to spend the necessary time on this kind of thing.

It is often said in academic circles that the study of parts of a scientific subject having no practical applications is an excellent preparation for something else later on; this sounds remarkably like the usual argument for a classical education. It is, of course, true that specialization can and often does begin too soon, but surely elementary education should be wide, not deep.

Another deterrent to the popularization of geology, so obvious as to make detailed discussion unnecessary, is the enormous number of zones and sub-zones now recognized in several systems; as, for example, the ammonites in the Jurassic and the graptolites in the Silurian. Furthermore, the names now applied to the ammonites in particular can only be described as appalling and quite sufficient in themselves to choke off any nascent interest in the subject, either in students or amateurs.

Finally, reference may be made to a complication for which there is an easy remedy. That is the practice of invariably quoting after the name of a fossil the authority by whom it was first described, even in supposedly popular or semi-popular writings. It is, of course, obvious that this must often be done in technical discussions by specialists, but it is submitted that it is entirely out of place in texts intended for students or amateurs. The effect on students is most depressing. They conclude that they are expected to learn three words for the name of every fossil, and also to remember the meaning of the abbreviation which often represents the name of the authority. Then there is the further complication of the brackets in which the name of the authority is often enclosed, which means that the said authority did not call the fossil by the name there printed, but something quite different. Incidentally, owing to a reason before discussed, nearly all names now have these brackets. The effect on amateurs is equally depressing.

Fortunately, petrology and mineralogy get on very well without such a system, although in point of fact in petrology there would probably be more excuse for it, since many rock-names have been used in varying senses; for example, the very common name dolerite. But it may well be considered what petrological literature would be like if one was com. pelled to write "basalt Pliny" or "granite God knows who" every time. For mineralogy the imagination reels at the prospect. Cannot palæontologists be induced to compare their own proceedings with this ?

The state of affairs here sketched must obviously be a passing phase, and there should eventually be found some means of simplification. If not, as a result of forty years experience of geology in all its branches, especially in teaching, it can only be said that the prospect is dark indeed.

\section{FREEDOM IN SCIENCE}

\section{BY DR. H. LOWERY}

$\mathbf{W}^{\mathrm{s}}$ AR-TIME necessity has required that science shall be planned in its applications to the prob. lems of national defence, food production, and other matters connected therewith. Indeed, the success or failure of a nation at war is easily seen to depend mainly upon how well it is able to utilize its scientific knowledge.

We must be careful, however, to distinguish between science on one hand and the applications of science on the other, a distinction that may be represented by the difference between science and technology. Science is concerned with the disinterested and dispassionate search for truth, and the man of science at work cannot see whither the road he travels will lead him. He must on occasion be prepared to follow what looks like a by-path, and it is vitally important that he should be free to do so if he chooses to leave his main road. A characteristic feature of technology, however, is that it is concerned with more or less clearly defined ends; the technologist sets out to achieve a definite object, improving a manufacturing process, carrying out to its logical conclusion some practical possibilities inherent in some general scientific principle, as, for example, when he sets out to design an electric motor for a particular purpose. While it is true that the technologist in his endeavour to achieve his goal may discover interesting new facts and may actually follow 
up some of these, nevertheless as a technologist he must carry out his original intention if he is to be successful at his job. Many of the larger research associations are sufficiently enlightened to recognize that their technologists may come across new possihilities, and are prepared to give their research workers their head, as a result of which countless advances in knowledge have been made in industrial laboratories, especially in the United States, which cannot be described other than as 'pure science'. On the other hand, not a little work of a distinctly technological nature has emerged from the universities.

No one will deny that technology is important in our life. Not even the most ardent scientific man would want to ban the practical achievements of the technologist. Unfortunately, the uncontrolled applications of the objective sciences as against the almost complete neglect of the applications of the social sciences have brought us perilously near the abyss of collapse of our civilization. As a result, there is a widespread belief, resting on a fallacy, that a complete planning of scientific investigation from above, presumably by the State, is the only way to our material salvation. The fallacy lies in the fact that scientific research as distinct from technological research cannot be planned. The man of science cannot see the end of his investigations and must be content to have faith and follow where truth leads; the man of science, unlike the technologist, cannot be judged by results, he cannot work to a time-table. His greatest moments of inspiration and insight may, and often do, occur when to the onlooker he is 'off duty'. Many of his most brilliant successes are the result of chance occurrences and of his freedom to take advantage of accidental happenings and observations, with the consequent need for change of direction in his work - -a diversion which under rigid planning from above would not be permitted.

There is one important implication in planning which is often overlooked by planners, and that is that the more life is planned the less freedom there is for the individual, a fact which has recently been stressed by the Archbishop of Canterbury. If science were completely planned, the research worker would no longer be independent or able to choose his own line of investigation. He would have to work con. tinuously according to some hypothetical formula or even political slogan, always being prepared to subordinate his intuitions, his conscience and his intellect to the dictates of the superimposed policy. We cannot contemplate any scientific man, not to speak of a Faraday, a Newton or a Maxwell, doing creative work under these conditions.

In a recent lecture to the London and Home Counties' Branch of the Institute of Physics, Dr. J. R. Baker, of the Department of Zoology of the University of Oxford, gave a stimulating account of the desiderata in the conditions under which the man of science should work, emphasizing in particular the importance of free choice in following up any new suggestion or chance occurrence in his investigations. Dr. Baker did not deny that the prime service of the man of science is to make his maximum contribution to the community through his own particular sphere of activity, which is akin to that of the artist and the musician. Without saying so explicitly, he did nevertheless suggest that the man of science working in the realm of ideas is akin to the student of æsthetics, a field in which the mere notion of planning is ludicrous. The guiding principle behind Dr. Baker's remarks was simply that planning of the work of the man of science will defeat its own ends through strangulation of the very spirit of science. He made it quite elear that he did not see any opposition between science and technology.

Indeed, in the subsequent discussion on Dr. Faker's lecture, it was easily seen that the technologists were in broad agreement with him on the need for freedom of the scientific worker. It was clear, however, that science is being attacked from within. Certain men of science, apparently misled by the undoubted need for the close linking of the objective sciences and the social sciences, have quite wrongly come to the conclusion that this link should take the form of complete planning of all science. Other motives, possibly of a purely political nature, seem also to be involved. It must not be forgotten, however, that the scientist, as a scientist, is not concerned with polities or even with applications, and therefore controls of any kind and the emotional associations which are invariably aroused by political action are inimical to his scientific advance.

During the vigorous and lengthy discussion which followed Dr. Baker's lecture, many aspects of scientific work were raised, a few only of which can be chosen for mention here. One speaker pointed out that in any country only a small number of people will either have the ability or resources to spend their lifetime in purely scientific research. Most prospective men of science are hampered by the need to make a living. They must therefore work in conjunction with research associations and other organizations which are primarily concerned with technological applications. It was pointed out, however, that even in associations of this kind, there is room for the scientifically inclined investigator to fulfil his hopes and ambitions and so follow up chance discoveries without concern as to any material end.

In this part of the discussion some members of the audience were worried as to the distinction between pure science and applied science. Rigorous definitions are impossible, but Dr. Baker suggested as the chief distinguishing characteristic the fact that scientific results are of permanent value, whereas technological results are of ephemeral value, being out-dated by further technological achievements in the same field -he quoted, for example, the out-dating of the musical box on the advent of the gramophone.

Another speaker referred to the ample resources for scientific research provided in the U.S.S.R. and emphasized that scientific work must have due relation to the needs of the country. Another point made was that the task of the man of science is to lead the people, and therefore he cannot remain aloof from political and social questions.

A scientific worker who had had experience both in industry and in university research emphasized that no gap really exists between pure and applied science, but pointed out that, on the whole, British industry has in general failed to realize how best to utilize the services of the scientifie man. It has expected final results too soon and has not been bold enough to pin its faith on the activities of the scientifically trained man. He pleaded for a more adventurous spirit in the attitude of British industry towards seience, and hoped that industry would give greater support to scientific research after the War than it has done in the past, as there can be no doubt that the development of new industries and the building up of a virile export trade cannot be accomplished without using to the full the contributions that men of science can make to the community. 
Throughout the discussion reference was frequently made to the need for the precise definition of terms, particularly the term 'truth' in the expression that 'science is concerned with the search for truth'. As one speaker aptly expressed the problem in reference to X-rays : Which is to be regarded as truth, $(a)$ the fact that we can measure the wave-length of X-rays, or $(b)$ the fact that we can use $\mathrm{X}$-rays for therapeutic purposes? Again in regard to chloroform, $(a)$ we know the chemical structure of the substance, and (b) we can employ it in order to alleviate pain. In each case are not the two aspects of our knowledge intimately bound together? This speaker concluded that we are unable to insist on the freedom of pure science.

From what has been said above, it will be clear that Dr. Baker opened up an important subject for consideration in war-time when everyone is deeply concerned with what we are to do with our lives both as individuals and as members of the community. His problems are of more than mere academical interest, and an outside observer at the discussion could not fail to be impressed with the sincere desire of the many scientific workers present to make their due contribution, in whatever form may be most appropriate, to the best needs of the community.

\section{THE MALACOLOGICAL SOCIETY OF LONDON, 1893-1943}

$\mathrm{O}$ N February 27, 1893, W. H. Hudleston, F.R.S., then president of the Geological Society, presided over a meeting at which the Malacological Society of London was inaugurated and the first council elected with Dr. Henry Woodward, F.R.S., as first president. On February 27 last the Society commemorated its jubilee in the rooms of the Linnean Society at its 415th meeting, with the twentieth president, Dr. A. T. Hopwood, in the chair.

Of the original seventy members Mr. E. R. Sykes (president 1904-7) and $\mathrm{Mr}$. J. R. le B. Tomlin. (president 1916-19) sent greetings, and Mr. A. S. Kennard (president 1922-25) gave an account of the Society's early history. Founded for the study of Mollusca, it owed much of its success to the enthusiasm of its first secretary, E. R. Sykes, and to the assistance of E. A. Smith, who was in charge of the British Museum Mollusca from 1871 until 1913. The Society early attracted notice in other countries and among the fifty-one corresponding members of its first year were included: W. H. Dall (1845-1927), who studied under Agassiz; C. Hedley (1862-1926), R. Tate (1840-1901), Joseph C. Verco (1851-1933), in Australia ; F. W. Hutton (1836-1905), H. Suter (18411918) in New Zealand ; H. C. Burnup (1852-I928), of the Natal Museum; Ph. Dautzenberg (1849-1935), of Paris, and the Marchese di Monterosato (1841--1927), of Palermo, two of the greatest private collectors; P. Fischer (1835-1893), best known of that family of many malacologists ; M. Cossmann (1850-1924), who despite the heavy duties of chief technical officer of the Chemin de fer du Nord wrote a revision of the Paris Basin mollusca; A. Brot (1821-1896), of Geneva ; S. Brusina (1845-1898), of Agram University; W. Kobelt (1840-1916); E. von Martens (1831-1904), first, and for twenty-one years, recorder of the molluscan section of the Zoological Record. The keen interest of H. A. Pilsbry, elected in 1894, brought in more American members, including C. W. Johnson (1863-1932), co-editor with him of the Nautilus. The cosmopolitan interest of the Society is marked by the fact that from 1908 until 1939 the number of corresponding members exceeded that of ordinary members. Nevertheless, the pulse of the Society has always centred in the meetings in London, which have mostly been held in the Linnean Society's rooms, though for a year (1928-29) the Society met in University College, and since 1939 many meetings have been held in the British Museum (Natural History).

The Society has always had good service from its officers, some of whom have served for long periods : J. H. Ponsonby was treasurer from 1900 until 1916 ; the present treasurer, Dr. R. L. Cox. was elected in: 1926 and since 1939 has also served as acting secretary vice Captain G. I. Crawford, absent on war service ; A. E. Salisbury (president 1933-36) served as secretary from 1919 until 1933 ; B. B. Woodward (president 1907-10) and E. A. Smith (president 1901-04) between them edited the Proceedings from 1893 until 1925, the former for periods of eleven and nine years and the latter for twelve years.

One object in founding the Society was to bring: palæontologists into touch with workers on recent Mollusca. A similar motive brought into being the Société malacologique de Belgique, the Annales of which contain far more fossil than recent work. Fossil Mollusca figure largely in the Society's Proceedings; one may instance the many papers by R. Bullen Newton (president 1910-13) and by G. C. Crick on cephalopods, notably two on the pro-ostracum and arms of belemnites. ${ }^{1}$. More recently, a series of papers from 1925 onwards by A. Wrigley on English Eocene and Oligocene gastropods illustrates the value of co-ordinating recent and fossil studies, while Dr. L. R. Cox has contributed many papers on Tertiary and Mesozoic shells, notably a study of the rudist genus Trechmanella ${ }^{2}$. Much of the work on British Pliocene and post-Pliocene non-marine Mollusca by A. S. Kennard and B. B. Woodward appeared in vols. 2-24 of the Proceedings. The close though informal association of the Society with the British Museum indicated by the above names was remarked upon by Dr. A. T. Hopwood in his presidential address to the jubilee meeting, and emphasized by Dr. C. Forster-Cooper in his reply.

Mr. R. Winckworth (president 1939-42) exhibited the Malacological and Conchological Magazine, produced by G. B. Sowerby in 1838 and 1839 with the object of inducing "noblemen and gentlomen" to found a society: he also gave some statistics of the Proceedings of the Malacological Society, now in its twenty-fifth volume and totalling 8,054 pages.

Anatomy very properly holds an important place in the Proceedings. The first paper read and published was on the anatomy of Paryphanta by H. H. Godwin-Austen (president 1897-99), who contributed so largely to our knowledge of Indian land Mollusca. M. F. Woodward, son of H. Woodward, had already written some important anatomical papers before his death in an accident at Ballynakill at the age of thirty-six : his most important work, that on I leurotomaria, was published elsewhere ${ }^{3}$. S. Pace, R. H. Burne, H. A. Pilsbry, H. Watson, N. H. Odhner, H. H. Bloomer and many others have added to this subject in the Proceedings, the last important paper being one by K. M. White on the pericardium and 